\title{
PEMBELAJARAN TERPADU TIPE WEBBED: SUATU PENDEKATAN PEMBELAJARAN TEMATIK DI MI/SD
}

\author{
Oleh: Syafrilianto ${ }^{1}$
}

\begin{abstract}
This article is a theoretical study to provide insight and understanding of webbed type integrated learning as one of the thematic learning approaches in MI / SD that are in line with the current 2013 curriculum. The webbed integrated learning is an integrated learning model that uses themes as the basis of learning by combining subject matter from multi disciplines or various subjects bound by one theme. Development of this approach begins by determining the specific themes that can be chosen between the teacher and the students, fellow teachers or students themselves. After the theme was agreed upon, it was followed by the selection of sub-themes with regard to their relation to other subjects. Furthermore, the sub-themes are planned for learning activities that students will do.The advantages of integrated learning webbed type for students is to obtain a complete view of the relationship of activities from different sciences.
\end{abstract}

Keyword: Integrated learning, Webbed, Elementary School

\section{PENDAHULUAN}

Dalam era globalisasi saat ini, kemajuan di segala bidang dan aspek kehidupan berkembang pesat terutama dalam bidang teknologi informasi. Kondisi ini menjadi tantangan bagi setiap bangsa dan negara di dunia untuk menciptakan sumber daya manusia yang unggul termasuk Indonesia agar tidak tertinggal dari bangsa-bangsa lain. Ketika suatu bangsa memiliki sumber daya manusia yang unggul, maka secara langsung maupun tidak langsung bangsa tersebut akan berada di garis terdepan dalam menguasai peradaban dunia sehingga mampu menjadi bangsa yang mandiri dan bermartabat.

Salah satu upaya pemerintah dalam menciptakan sumber daya manusia yang unggul tersebut adalah melalui pendidikan. Melalui pendidikan yang berkualitas, maka akan mampu untuk melahirkan generasi muda yang memiliki kompetensi yang dibutuhkan demi kamajuan dan kemandirian bangsa Indonesia di masa depan. Diantara upaya yang telah dilakukan pemerintah dalam mewujudkan hal itu adalah dengan meningkatkan mutu pendidikan melalui penyelenggaraan suatu sistem pendidikan nasional sebagaimana tercantum dalam UndangUndang Nomor 20 Tahun 2003 tentang Sistem Pendidikan Nasional. ${ }^{2}$

Sistem Pendidikan Nasional dalam kaitannya dengan peningkatan mutu pendidikan diarahkan untuk meningkatkan kualitas manusia Indonesia seutuhnya melalui olah batin, olah pikir, olah rasa dan olah kinerja yang bermuara pada pengembangan peserta didik yang meliputi aspek transendensi, aspek kognisi, aspek afeksi, dan aspek psikomotoris. Dengan demikian, output sumber daya manusia yang dihasilkan memiliki daya saing dalam menghadapi tantangan global, artinya lulusan yang dihasilkan sesuai dengan tuntutan kebutuhan berbasis potensi sumber daya alam Indonesia.

\footnotetext{
${ }^{1}$ Dosen Prodi PGMI FTIK IAIN Padangsidimpuan (Keahlian pada Konsep Dasar IPA pada MI/SD

${ }^{2}$ Trianto, Model Pembelajaran Terpadu (Jakarta: Bumi Aksara, 2014), h. 6
}

Pembelajaran Terpadu................................................................................... Syafrilianto 
Selanjutnya, sebagai implementasi Undang-Undang Nomor 20 Tahun 2003, maka dijabarkan ke dalam beberapa peraturan antara lain Peraturan Pemerintah Nomor 19 Tahun 2005 tentang Standar Nasional Pendidikan.Peraturan Pemerintah ini memuat tentang delapan standar nasional pendidikan yang perlu disusun dan dilaksanakan oleh stakeholder dalam bidang pendidikan, mulai dari tingkat pusat sampai ke tingkat daerah bahkan sampai ke tingkat satuan pendidikan. Delapan standar yang dimaksud adalah standar isi, standar proses, standar kompetensi lulusan, standar pendidik dan tenaga kependidikan, standar sarana dan prasarana, standar pengelolaan, standar pembiayaan, dan standar penilaian pendidikan.

Standar proses merupakan sebuah pedoman, atau tahapan langkah-langkah bagi para guru ketika mereka memberikan pembelajaran dalam kelas, dengan harapan proses pendidikan dapatberlangsung efektif, efisien dan inovatif sehingga lulusan yang dihasilkan sesuai dengan kompetensi yang telah ditetapkan. Permendikbud nomor 65 tahun 2013 mengamanatkan bahwa proses pembelajaran pada satuan pendidikan harus diselenggarakan secara interaktif, inspiratif, menyenangkan, menantang, memotivasi peserta didik untuk berpartisipasi aktif, serta memberikan ruang yang cukup bagi prakarsa, kreativitas, dan kemandirian sesuai dengan bakat, minat, dan perkembangan fisik serta psikologis peserta didik. Untuk merealisasikan peraturan tersebut, salah satunya dapat dilakukan melalui penggunaan model pembelajaran terpadu terutama pada tingkat satuan pendidikan dasar (SD, SMP). Melalui pembelajaran terpadu peserta didik memperoleh pengalaman belajar langsung sehingga dapat menambah kekuatan untuk menerima, menyimpan dan menerapkan konsep-konsep yang telah dipelajarinya.

Sebagai contoh, pembelajaran terpadu dapat dikemas dengan tema tentang suatu wacana yang dibahas dari berbagai sudut pandang atau disiplin keilmuan yang mudah dikenal dan dipahami oleh peserta didik. Dalam pembelajaran terpadu, suatu tema dapat dibahas dari berbagai bidang kajian, misalnya dalam bidang kajian IPA tentang tema lingkungan dapat dibahas dari aspek makhluk hidup dan proses kehidupan (biologi), energi dan perubahannya (fisika), serta materi dan sifatnya (kimia). Dengan demikian melalui pembelajaran terpadu, beberapa konsep yang relevan dalam suatu tema tertentu tidak perlu dibahas berulang kali dalam bidang kajian yang berbeda, sehingga penggunaan waktu dalam kegiatan pembelajaran lebih efisien serta pencapaian tujuan pembelajaran juga diharapkan lebih efektif. ${ }^{3}$

\section{PEMBAHASAN}

\section{A. Pengertian dan Makna Pembelajaran Terpadu}

Istilah Integrated atau terpadu bisa mengacu pada integrated curricula (kurikulum terpadu),integrated approach (pendekatan terpadu) atau integrated learning(pembelajaran). Terkait dengan pembelajaran terpadu (integrated learning), keterpaduan dapat diartikan sebagai metode pengorganisasian pembelajaran yang menggunakan beberapa bidang mata pelajaran yang sesuai.

Pembelajaran terpadu merupakan suatu aplikasi salah satu strategi pembelajaran berdasarkanpendekatan kurikulum terpaduyang bertujuan untuk menciptakan atau membuat proses pembelajaran secara relevan dan bermakna bagi anak. ${ }^{4} \mathrm{Hal}$ ini berarti bahwa dalam pembelajaran terpadu dapat didasarkan pada pendekatan inquiry, yaitu pembelajaran yang melibatkan siswa mulai dari merencanakan, mengeksplorasi, dan brain storming dari

\footnotetext{
${ }^{3}$ Trianto, Model....,h. 17

${ }^{4}$ Muhajir dan Khatimah,YR, Buku Pedoman Pengembangan dan Implementasi Kurikulum 2013. Jakarta: Kemendikbud, 2013), h. 34
}

Pembelajaran Terpadu.........................................................................Syafrilianto 
siswa.Dengan pendekatan terpadu siswa didorong untuk berani bekerja secara kelompok dan belajar dari hasil pengalamannya sendiri.Dalam pelaksanaannya anak dapat diajak berpartisipasi aktif dalam mengeksplorasi topik atau kejadian, serta mempelajari proses dan isi (materi) lebih dari satu bidang studi pada waktu yang sama.Pembelajaran terpadu sangat memperhatikan kebutuhan anak sesuai dengan perkembangannya secara holistik dengan melibatkan keaktifan siswa dalam proses pembelajaran baik fisik maupun emosionalnya. Untuk itu aktivitas yang diberikan meliputi aktif mencari, menggali, dan menemukan konsep serta prinsip keilmuan yang holistik, bermakna, dan otentik sehingga siswa dapat menerapkan perolehan belajar untuk memecahkan masalah-masalah yang nyata di dalam kehidupan sehari-hari.

Selanjutnya, pembelajaran terpadu dapat juga bermakna sebagai suatu pendekatan dalam pembelajaran yang secara sengaja mengaitkan beberapa aspek baik dalam intra matapelajaran maupun antar matapelajaran. Dengan adanya pemaduan itu siswa akan memperoleh pengetahuan dan keterampilan secara utuh sehingga pembelajaran menjadi bermakna bagi siswa. Bermakna disini memberikan arti bahwa pada pembelajaran terpadu siswa akan dapat memahami konsepkonsep yang mereka pelajari melalui pengalaman langsung dan nyata yang menghubungkan antar konsep dalam intra mata pelajaran maupun antar mata pelajaran.Jika dibandingkan dalam konsep konvensional, maka pembelajaran terpadu lebih menekankan keterlibatan siswa dalam belajar, sehingga siswa terlibat aktif dalam proses pembelajaran untuk pembuatan keputusan.

\section{B. Karakteristik Pembelajaran Terpadu}

Pembelajaran terpadu sebagai suatu proses pembelajaran memiliki beberapa karakteristik yaitu aktif, kontekstual, otentik, holistik, keterkaitan muatan atau materi. ${ }^{5}$

1. Aktif (pembelajaran terpusat pada anak)

Pembelajaran terpadu dikatakan sebagai pembelajaran yang terpusat pada anak, karena pada dasarnya pembelajaran terpadu merupakan suatu system pembelajaran yang memberikan keleluasaan pada siswa, baik secara individu maupun secara kelompok.Siswa dapat aktif mencari, menggali, dan menemukan konsep serta prinsip-prinsip dari suatu pengetahuan yang harus dikuasai sesuai dengan perkembangannya.

2. Kontekstual (menekankan pembentukan pemahaman dan kebermaknaan)

Pembelajaran terpadu mengkaji suatu fenomena dari berbagai macam aspek yang membentuk semacam jalinan antarskemata yang dimiliki oleh siswa, sehingga akan berdampak pada kebermaknaan dari materi yang dipelajari siswa.Hasil nyata diperoleh dari berbagai konsep dan keterkaitannya dengan konsep-konsep lain yang dipelajari, sehingga kegiatan belajar menjadi lebih bermakna.Hal ini diharapkan berimplikasi pada kemampuan siswa untuk dapat menerapakan perolehan belajarnya pada pemecahan masalahmasalah yang nyata dalam kehidupannya.

3. Otentik (belajar melalui proses pengalaman langsung)

Dalam pembelajaran terpadu diprogramkan untuk melibatkan siswa secara langsung pada konsep dan prinsip yang dipelajari dan memungkinkan siswa belajar dengan melakukan kegiatan secara langsung. Siswa akan memahami hasil belajarnya secara langsung serta sesuai dengan fakta dan peristiwa yang mereka alami, bukan sekedar informasi dari gurunya. Guru lebih banyak bertindak sebagai fasilitator yang membimbing

\footnotetext{
${ }^{5}$ Depdikbud, Model-Model Pembelajaran Dirjen Pendidikan Dasar dan Menengah Departemen Pendidikan Nasional (Jakarta: Depdikbud, 2002), h. 56
}

Pembelajaran Terpadu Syafrilianto 
siswa agar tujuan pembelajaran tercapai, sedangkan siswa sebagai aktor pencari fakta dan informasi untuk mengembangkan pengetahuannya.

4. Holistik (lebih memperhatikan proses daripada hasil semata)

Pendekatan yang dikembangkan dalam pembelajaran terpadu adalah pendekatan discovery inquiry (penemuan terbimbing) yang melibatkan siswa secara aktif dalam proses pembelajaran yaitu mulai dari perencanaan, pelaksanaan sampai proses evaluasi. Pembelajaran terpadu dilaksanakan dengan melihat keinginan, minat, dan kemampuan siswa sehingga memungkinkan siswa termotivasi untuk belajar terus-menerus.

5. Sarat dengan muatan keterkaitan

Pembelajaran terpadu memusatkan perhatian pada pengamatan dan pengkajian suatu gejala atau peristiwa dari beberapa matapelajaran sekaligus, tidak dari sudut pandang yang parsial. Sehingga memungkinkan siswa untuk memahami suatu fenomena pembelajaran dari segala sisi, sehinggaakan membuat siswa lebih arif dan bijak dalam menyikapi atau menghadapi kejadian yang ada.

\section{Tujuan Pembelajaran Terpadu}

Pembalajaran terpadu dikembangkan selain untuk mencapai tujuan pembelajaran yang telah ditetapkan, diharapkan siswa juga dapat :

1. Meningkatkan pemahaman konsep yang dipelajarinya secara lebih bermakna.

2. Mengembangkan keterampilan menemukan, mengolah, dan memanfaatkan informasi.

3. Menumbuhkembangkan sikap positif, kebiasaan baik, dan nilai-nilai luhur yang diperlukan dalam kehidupan.

4. Menumbuh kembangkan keterampilan sosial seperti kerjasama, toleransi, komunikasi, serta menghargai pendapat orang lain.

5. Meningkatkan minat dalam belajar.

6. Memilih kegiatan yang sesuai dengan minat dan kebutuhannya.

\section{Pembelajaran Terpadu Tipe Webbed dan Langkah-Langkahnya}

Webbed seperti sebuah teleskop yang memiliki pandangan luas dari seluruh kumpulan sebagai satu tema, berbentuk jaringan laba-laba yang tersusun atas berbagai elemen. ${ }^{6}$ Model pembelajaran terpadu tipe webbed merupakan model pembelajaran terpadu yang menggunakan tema sebagai dasar pembelajaran. Kurikulum jaring laba-laba (webbed) menurut Fogarty merupakan representai dari pendekatan tematik untuk memadukan materi pelajaran yang berasal dari multi disiplin ilmu atau berbagai mata pelajaran yang diikat oleh satu tema.Pengembangan pendekatan ini dimulai dengan menentukan tema tertentu.Tema yang ditetapkan dapat dipilih antara guru dengan siswa, sesama guru atau siswa sendiri. Setelah tema disepakati maka dilanjutkan dengan pemilihan sub-sub tema dengan memperhatikan kaitannya dengan matapelajaran yang lain.

Langkah yang dilakukan selanjutnya adalah dari sub-sub tema tersebut direncanakan aktivitas belajar yang harus dilakukan siswa. Keuntungan pembelajaran terpadu tipe webbedbagi siswa adalah diperolehnya pandangan hubungan yang utuh tentang kegiatan dari ilmu-ilmu yang berbeda. Contoh: Siswa dan guru menentukan tema misalnya air, maka guru-guru matapelajaran dapat mengajarkan tema air itu ke dalam sub-sub tema misalnya siklus air, kincir angin, air

\footnotetext{
h. 65

${ }^{6}$ Fogarty, R, The Mindful School: How to Integrate The Curricula (Illinois: IRI/ Skylight Publishing, 1991),
}

Pembelajaran Terpadu.........................................................................Syafrilianto 
waduk, air sungai, bisnis air dari PDAM yang tergabung dalam matapelajaran matematika, IPS, IPA.

Adapun langkah-langkah dalam pembelajaran terpadu tipe webbedsecara umum dapat dilakukan sebagai berikut ${ }^{7}$ :

1. Guru memilih tema utama dan tema lain dari beberapa standar kompetensi lintas mata pelajaran/bidang Studi.

2. Guru menyiapkan tema-tema yang telah terpilih, misalnya tema matematika, kesenian, bahasa dan IPS yang sesuai dengan tema utama yang telah ditetapkan.

3. Guru menjelaskan tema-tema yang terkait sehingga materinya lebih luas.

4. Guru memilih konsep atau informasi yang bisa mendorong belajar siswa dengan pertimbangan lain yang memang sesuai dengan prinsip-prinsip pembelajaran terpadu.

5. Penetapan kegiatan/ kontrak belajar, antara lain:

a. Pengumpulan informasi (kelompok, individual; membaca sumber, wawancara dengan nara sumber, pengamatan lapangan, eksperimentasi).

b. Pengolahan informasi (analisis, komparasi, sintesis).

c. Penyusunan laporan (verbal, grafis, model).

d. Penyajian laporan (tertulis, lisan, unjuk kerja; individual, kelompok, presentasi, dll).

e. Penilaian atau evaluasi (proses, produk).

\section{E. Kelebihan dan Kekurangan Pembelajaran Terpadu tipe Webbed}

Seperti Model-model pembelajaran terpadu yang lainnya, Model pembelajaran terpadu tipe Webbed juga memiliki berbagai kelebihan ketika diaplikasikan dalam pembelajaran di sekolah. Kelebihan Model pembelajaran terpadu tipe Webbed menurut Fogarty antara lain yaitu:

1. Memberikanmotivasimelaluipemilihantemayang lebih menarik.

2. ModelWebbed atau bagianpenulisanpendekatanini akrab bagiguruberpengalaman danmerupakan modelperencanaan kurikulumyang cukup sederhanabagiguruyang belum berpengalaman.

3. Memfasilitasi perencanaan kerja tim guru antar bidang mata pelajaran dalam merangkai tema ke semua konten bidang mata pelajaran.

4. Model webbed menyediakan sebuah gambaran yang jelas dan payung motivasi bagi siswa, artinya pendekatan tematik dapat memudahkan bagi mereka untuk melihat bagaimana perbedaan aktivitas dan ide-ide yang berkaitan.

Selanjutnya, model pembelajaran terpadu tipe Webbed juga memiliki berbagai kekurangan ketika diaplikasikan di sekolah. Kekurangan tipe webbed menurut Fogarty antara lain sebagai berikut:

1. Sulit dalam menyeleksi tema

2. Cenderung untuk merumuskan tema-tema yang dangkal.

3. Ketika pembelajaran dilaksanakan, guru lebih memusatkan perhatian pada kegiatan pembelajaran dibandingkan dengan pengembangan konsep.

4. Diperlukan kehati-hatian dalam menerapkan model webbedsehingga tidakmengorbankanruang lingkuplogis danesensisertaurutanyang melekat di dalamsetiap disiplin ilmu.

${ }^{7}$ Rizka, P. Pembelajaran Terpadu Model Webbed, 2013) [Online]. Tersedia: http://rizkapratiwijaya.blogspot.com/2013/04/pembelajaran-terpadu-model-webbed.html[8 September 2014].

Pembelajaran Terpadu..................................................................................Syafrilianto 
5. Guru dapatterjebak dalampenyusunan kegiatan pembelajaranyang mungkin memerlukan waktu yang lama namun tidak ada jaminan bahwa pembelajaran tersebut dapat digunakan padatahun mendatang karena biasanya tidak ada pengulangan tema.

\section{F. Tahap-Tahap Perencanaan dan Contoh Pembelajaran Terpadu tipe Webbed}

Tahap-tahap perencanaan pembelajaran terpadu tipeWebbed dapat dilakukan melalui beberapa langkah berikut ini:

1. Melakukan Pemetaanterhadap Kompetensi Dasar mata pelajaran yang akan dipadukan.

2. Menentukan tema berdasarkan Kompetensi Dasar yang telah dipetakan.

3. Menjabarkan kompetensi dasar ke dalam indikator sesuai dengan tema.

4. Mengembangkan Silabus Pembelajaran.

5. Menyusun Rencana Pelaksanaan Pembelajaran.

Oleh karena itu, berdasarkan langkah-langkah diatas, maka salah satu bentuk implementasi terhadap perencanaan pembelajaran terpadu tipe Webbed pada mata pelajaran IPA, PPKn, Bahasa Indonesia dan Matematika di MI/SD sebagai berikut:

1. Pemetaan Kompetensi Dasar

Pada langkah pertama ini, kegiatan yang perlu dilakukan antara lain:

a. Mengidentifikasi Kompetensi Inti dan Kompetensi Dasar pada mata pelajaran yang akan dipadukan pada tingkat kelas yang sama (Contoh: IPA, PPKn, Matematika, Bahasa Indonesia). Langkah ini dilakukan untuk memperoleh gambaran yang utuh dan menyeluruh dari mata pelajaran yang akan dipadukan.

b. Menentukan Kompetensi Dasar yang mengikat antar mata pelajaran berdasarkan tema yang akan dipilih.

2. Penentuan Tema

Setelah melakukan pemetaan Kompetensi Dasar, langkah berikutnya adalah menentukan tema.Tema yang ditentukan harus relevan dengan kompetensi dasar yang telah dipetakan. Berikut ini terdapat beberapa syarat yang perlu diperhatikan dalam menentukan tema yaitu:

a. Tema yang dipilih memiliki cakupan atau dapat diaplikasikan secara luas (Applies broadly), artinya dapat dihubungkan dengan beberapa bidang ilmu.

b. Temayang dipilh dapat meningkatkan minat (applies persuasively) serta relevan dengan pengalaman pribadi siswa, artinya sesuai dengan keadaan lingkungan setempat.

c. Dapat mengungkapkan pola-pola mendasar serta menunjukkan persamaan dan perbedaan (discloses fundamental pattern, reveals similarities and contrast).

d. Tema yang dipilih harus lebih menarik ketika diangkat dalam suatu pembelajaran (fascinates)

Berdasarkan pertimbangan di atas sertadengan memperhatikan Kompetensi Dasar pengikat antar mata pelajaran IPA, PPKn, Matematika dan Bahasa Indonesia, maka tema yang akan digunakan dalam pembelajaran ini adalah "Pencemaran Lingkungan" karena tema ini dapat menjadi perekat antar Kompetensi Dasar yang telah dipilih.

Pembelajaran Terpadu................................................................................... Syafrilianto 
3. Penjabaran Kompetensi Dasar dalam Indikator

Tabel 1. Pemetaan KI, KD dan penjabarannya ke dalam Indikator Pembelajaran Terpadu Tipe Webbed di MI/SD

\begin{tabular}{|c|c|c|c|}
\hline $\begin{array}{l}\text { Bidang } \\
\text { Studi }\end{array}$ & Kompetensi Inti & Kompetensi Dasar & Indikator \\
\hline IPA & $\begin{array}{l}\text { Memahami pengetahuan } \\
\text { (faktual, konseptual, dan } \\
\text { prosedural) berdasarkan } \\
\text { rasa ingin tahunya } \\
\text { tentang ilmu } \\
\text { pengetahuan, teknologi, } \\
\text { seni, budaya terkait } \\
\text { fenomena dan kejadian } \\
\text { tampak mata. }\end{array}$ & $\begin{array}{l}\text { Mendeskripsikan } \\
\text { pencemaran dan } \\
\text { dampaknya bagi } \\
\text { makhluk hidup }\end{array}$ & $\begin{array}{l}\text { Menjelaskan } 3 \text { penyebab } \\
\text { terjadinya pencemaran } \\
\text { lingkungan } \\
\text { Menyebutkan } 5 \text { dampak } \\
\text { pencemaran lingkungan } \\
\text { bagi kesehatan manusia }\end{array}$ \\
\hline PPKn & $\begin{array}{l}\text { Memahami pengetahuan } \\
\text { (faktual, konseptual, dan } \\
\text { prosedural) berdasarkan } \\
\text { rasa ingin tahunya } \\
\text { tentang ilmu } \\
\text { pengetahuan, teknologi, } \\
\text { seni, budaya terkait } \\
\text { fenomena dan kejadian } \\
\text { tampak mata. }\end{array}$ & $\begin{array}{l}\text { Memahami } \\
\text { karakteristik daerah } \\
\text { tempat tinggalnya } \\
\text { dalam kerangka } \\
\text { Negara Kesatuan } \\
\text { Republik Indonesia } \\
\text { (NKRI) }\end{array}$ & $\begin{array}{l}\text { Mengidentifikasi tempat- } \\
\text { tempat kumuh yang ada di } \\
\text { sekitar lingkungan tempat } \\
\text { tinggal } \\
\text { Mendeskripsikan kebersihan } \\
\text { parit dan selokan, dan } \\
\text { sungai yang ada di } \\
\text { lingkungan tempat tinggal }\end{array}$ \\
\hline Matematika & $\begin{array}{l}\text { Memahami pengetahuan } \\
\text { (faktual, konseptual, dan } \\
\text { prosedural) berdasarkan } \\
\text { rasa ingin tahunya } \\
\text { tentang ilmu } \\
\text { pengetahuan, teknologi, } \\
\text { seni, budaya terkait } \\
\text { fenomena dan kejadian } \\
\text { tampak mata. }\end{array}$ & $\begin{array}{l}\text { Memahami teknik } \\
\text { penataan data dari dua } \\
\text { variabel menggunakan } \\
\text { tabel, grafik batang, } \\
\text { diagram lingkaran, } \\
\text { dan grafik garis }\end{array}$ & $\begin{array}{l}\text { Menggambarkan grafik } \\
\text { hubungan antara produksi } \\
\text { sampah dan tingkat } \\
\text { pencemaran lingkungan } \\
\text { Menyusun tabel tentang } \\
\text { proses pembuatan kompos } \\
\text { dengan memanfaatkan } \\
\text { limbah rumah tangga } \\
\text { masyarakat sekitar. }\end{array}$ \\
\hline $\begin{array}{l}\text { Bahasa } \\
\text { Indonesia }\end{array}$ & $\begin{array}{l}\text { Memahami pengetahuan } \\
\text { (faktual, konseptual, dan } \\
\text { prosedural) berdasarkan } \\
\text { rasa ingin tahunya } \\
\text { tentang ilmu } \\
\text { pengetahuan, teknologi, } \\
\text { seni, budaya terkait } \\
\text { fenomena dan kejadian } \\
\text { tampak mata. }\end{array}$ & $\begin{array}{l}\text { Memahami teks hasil } \\
\text { observasi, tanggapan } \\
\text { deskriptif, eksposisi, } \\
\text { eksplanasi, dan cerita } \\
\text { pendek baik melalui } \\
\text { lisan maupun tulisan }\end{array}$ & $\begin{array}{l}\text { Menceritakan kembali } \\
\text { proses pengolahan limbah } \\
\text { rumah tangga agar lebih } \\
\text { produktif dan bermanfaat } \\
\text { berdasarkan laporan } \\
\text { penelitian } \\
\text { Menjelaskan secara lisan } \\
\text { tindakan preventif terhadap } \\
\text { pencemaran lingkungan }\end{array}$ \\
\hline Tema & \multicolumn{3}{|c|}{ "Pencemaran Lingkungan" } \\
\hline
\end{tabular}


Oleh karena itu, berdasarkan uraian langkah-langkah di atas, maka dapat digambarkan bagan pembelajaran terpadu tipe webbedpada mata pelajaran antarbidang studi IPA, PPKn, Matematika dan Bahasa Indonesia dengan tema "Pencemaran Lingkungan" sebagai beri

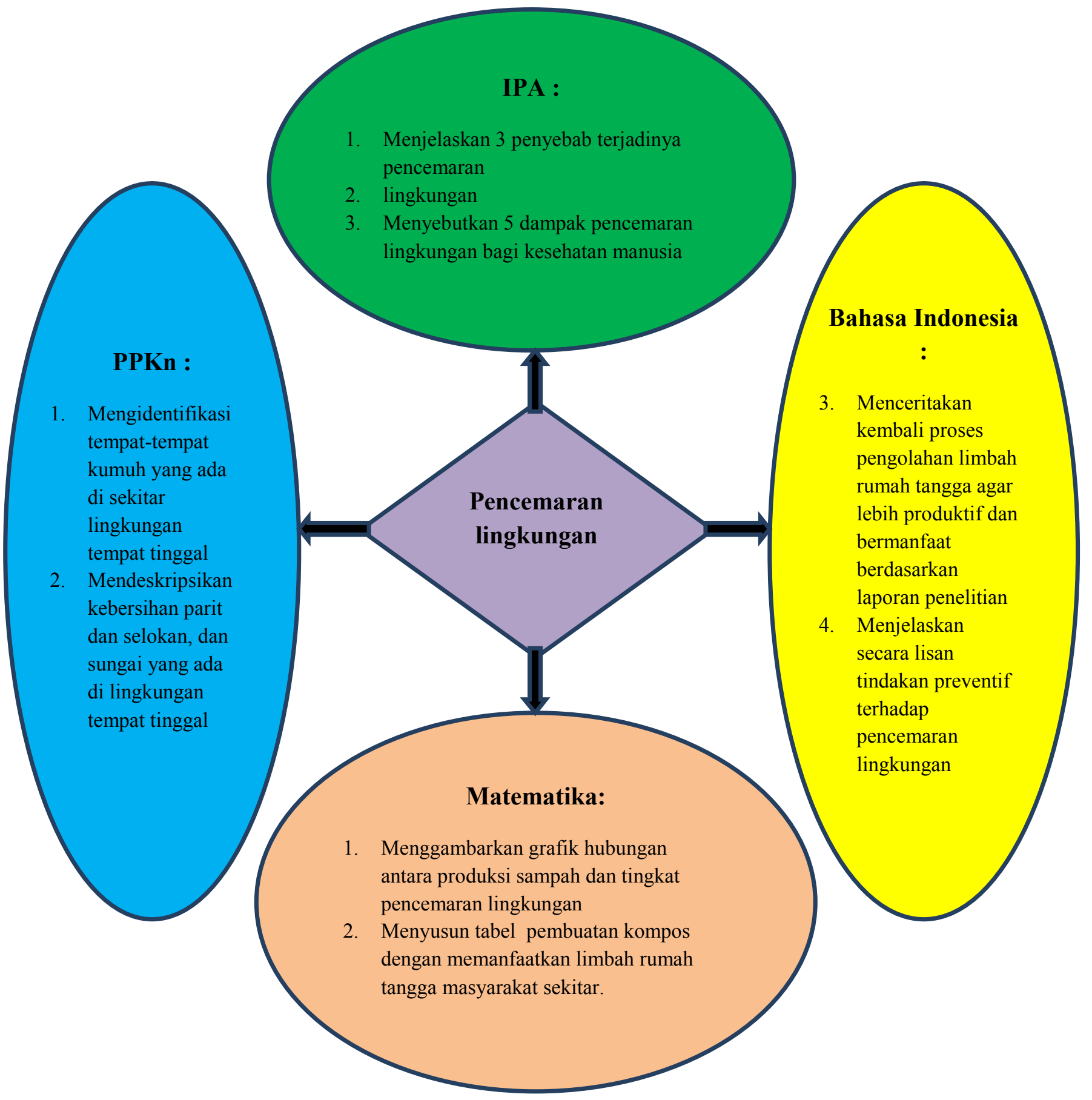

Gambar 1. Bagan Pembelajaran Terpadu Tipe Webbed dengan Tema "Pencemaran Lingkungan" 


\section{G. Contoh Rancangan RPP Pendekatan Terpadu tipe Webbed}

$\begin{array}{lll}\begin{array}{l}\text { Satuan Pendidikan } \\ \text { MataPelajaran }\end{array} & : & \begin{array}{l}\text { MI/SD } \\ \text { IPA, MTK, PPKn, Bahasa Indonesia } \\ \text { (Tematik) }\end{array} \\ \text { Kelas/Semester } & : & \text { SemesterI } \\ \text { Tema } & : & \text { Pencemaran Lingkungan } \\ \text { AlokasiWaktu } & : & 2 X 40 \text { menit(2kalitatapmuka) }\end{array}$

a. KompetensiDasar

1. Mendeskripsikan pencemaran dan dampaknya bagi makhluk hidup

2. Memahami karakteristik daerah tempat tinggalnya dalam kerangka Negara Kesatuan Republik Indonesia (NKRI)

3. Memahami teknik penataan data dari dua variabel menggunakan tabel, grafik batang, diagram lingkaran, dan grafik garis.

4. Memahami teks hasil observasi, tanggapan deskriptif, eksposisi, eksplanasi, dan cerita pendek baik melalui lisan maupun tulisan.

a) Indikator

1. Menjelaskan penyebab terjadinya pencemaran lingkungan.

2. Menyebutkandampak pencemaran lingkungan bagi kesehatan manusia.

3. Mengidentifikasi tempat-tempat kumuh yang ada di sekitar lingkungan tempat tinggal.

4. Mendeskripsikan kebersihan parit, selokan, dan sungai yang ada di lingkungan tempat tinggal.

5. Menggambarkan grafik hubungan antara produksi sampah dan tingkat pencemaran lingkungan.

6. Menyusun tabel tentang proses dan bahan pembuatan kompos dengan memanfaatkan limbah rumah tangga masyarakat sekitar.

7. Menceritakan kembali proses pengolahan limbah rumah tangga agar lebih produktif dan bermanfaat berdasarkan laporan penelitian.

8. Menjelaskan secara lisan tindakan preventif terhadap pencemaran lingkungan.

b) Tujuan Pembelajaran

Setelah melakukan kegiatan pembelajaran ini, siswa dapat:

1. Menjelaskan 3 penyebab terjadinya pencemaran lingkungan.

2. Menyebutkan 4 dampak pencemaran lingkungan bagi kesehatan manusia.

3. Mengidentifikasi tempat-tempat kumuh yang ada di sekitar lingkungan tempat tinggal.

4. Mendeskripsikan secara kualitatif kebersihan parit, selokan, dan sungai yang ada di lingkungan tempat tinggal.

5. Menggambarkan grafik hubungan antara produksi sampah dan tingkat pencemaran lingkungan.

6. Menyusun tabel pembuatan kompos dengan memanfaatkan limbah rumah tangga masyarakat sekitar.

7. Menceritakan kembali proses pengolahan limbah rumah tangga agar lebih produktif dan bermanfaat berdasarkan laporan penelitian.

8. Menjelaskan secara lisan tindakan preventif terhadap pencemaran lingkungan. 
c) Materi

1. Pencemaran Lingkungan dan Dampaknya

Pencemaran dapat timbul sebagai akibat kegiatan manusia ataupun disebabkan oleh alam (misal gunung meletus, gas beracun).Ilmu lingkungan biasanya membahas pencemaran yang disebabkan oleh aktivitas manusia, yang dapat dicegah dan dikendalikan.Karena kegiatan manusia, pencermaran lingkungan pasti terjadi.Pencemaran lingkungan tersebut tidak dapat dihindari.Yang dapat dilakukan adalah mengurangi pencemaran, mengendalikan pencemaran, dan meningkatkan kesadaran dan kepedulian masyarakat terhadap lingkungannya agar tidak mencemari lingkngan.Zat atau bahan yang dapat mengakibatkan pencemaran di sebut polutan. Syarat-syarat suatu zat disebut polutan bila keberadaannya dapat menyebabkan kerugian terhadap makluk hidup. Contohnya, karbon dioksida dengan kadar 0,033\% di udara berfaedah bagi tumbuhan, tetapi bila lebih tinggi dari 0,033\% dapat memberikan efek merusak.

Adapun beberapa dampak pencemaran lingkungan antara lain yaitu:

1. Punahnya species

2. Peledakan Hama

3. Punahnya Keseimbangan Lingkungan

4. Kesuburan Tanah Berkurang

5. Keracunan dan Penyakit

6. Pemekatan Hayati

7. Terbentuknya Lubang Ozon dan Efek Rumah Kaca

\section{Karakteristik Wilayah Tempat Tinggal}

Daerah atau wilayah tempat tinggal merupakan daerah yang kita tempati dalam salah salah satu bagian wilayah Negara Kesatuan Republik Indonesia.Sebagai negara kepulauan (maritim) dan negara agraris (mayoritas petani), wilayah Indonesia terdiri dari 34 Provinsi.Jumlah penduduk Indonesia mencapai lebih dari 240 juta jiwa dengan berbagai suku, agama, dan ras yang tersebar di berbagai pulau dan kepulauan.Setiap daerah di Indonesia memiliki ciri khusus antara lain yaitu sebagai Flora dan Faunanya, terbagi 3 wilayah yaitu Asiatis (Barat), Peralihan (Tengah), dan Australis (Timur) di mana perbedaan di setiap daerah dan karakteristiknya ditentukan oleh keadaan geografisnya.

3. Penyusunan Tabel dan Grafik

Tabel adalah daftar berisi ikhtisar sejumlah (besar) data informasi, biasanya berupa kata-kata dan bilangan yg tersusun secara bersistem, urut ke bawah dalam lajur dan deret tertentu dengan garis pembatas sehingga dapat dengan mudah disimak .

Grafik adalah lukisan pasang surut suatu keadaan dengan garis atau gambar .adapun macam-macam grafik terdiri atas:

1) Grafik garis: mengambarkan kecenderungan-kecenderungan hubungan dan rangkaian data terutama untuk data yang berkelanjutan .

2) Grafik batang: digambarkan oleh batang-batang secara vertikal atau horosontal, panjagnya batang menunjukan presentasi data.

3) Grafik lingkaran: penyajian data statistik dengan menggunakan gambar yang berbentuk lingkaran. Bagian-bagian dari daerah lingkaran menunjukkan bagian bagian atau persen dari keseluruhan. Untuk membuat diagram lingkaran, terlebih 
dahulu ditentukan besarnya persentase tiap objek terhadap keseluruhan data dan besarnya sudut pusat sektor lingkaran.

4) Grafik wilayah/gambar: melukiskan keadaan dihubungkan dengan tempat kejadian itu berada .

d) Pendekatan/Strategi/MetodePembelajaran

1. Pendekatan : Scientific

2. Metode : Ceramah, Diskusi

3. Model : DiscoveryLearning

e) Kegiatan Pembelajaran

\begin{tabular}{|c|c|c|c|}
\hline Kegiatan & $\begin{array}{l}\text { Langkah-langkah } \\
\text { ModelDiscovery }\end{array}$ & DeskripsiKegiatan & \begin{tabular}{|l} 
Alokasi \\
Waktu
\end{tabular} \\
\hline Pendahuluan & $\begin{array}{l}\text { Menciptakan } \\
\text { Situasi(Stimulasi) }\end{array}$ & Disesuaikan & 10 menit \\
\hline KegiatanInti & 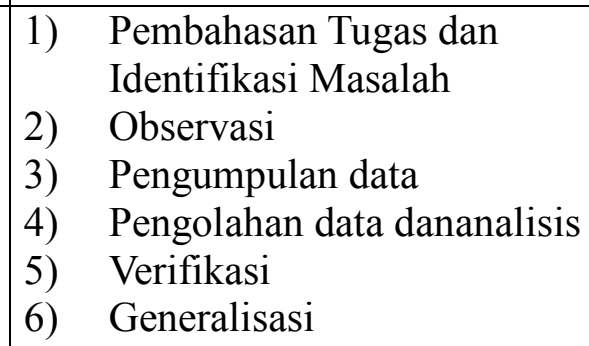 & Disesuaikan & 50 menit \\
\hline Penutup & $\begin{array}{l}\text { Kesimpulan } \\
\text { Tugas }\end{array}$ & Disesuaikan & 20 menit \\
\hline
\end{tabular}

f) Penilaian

\begin{tabular}{|l|l|}
\hline \multicolumn{1}{|c|}{ Metode } & \multicolumn{1}{c|}{ Bentuk Instrumen } \\
\hline$\bullet$ Sikap & $\bullet$ Lembar Pengamatan Sikapdan Rubrik \\
\hline$\bullet$ TesTertulis & $\bullet$ TesUraiandan Pilihan Ganda \\
\hline
\end{tabular}




\section{KESIMPULAN DAN SARAN}

\section{A. Kesimpulan}

Berdasarkan pemaparan dan uraian dalam makalah ini, maka dapat diperoleh beberapa kesimpulan yaitu:

1. Keterpaduan dalam pembelajaran dapat diartikan sebagai metode pengorganisasian pembelajaran menggunakan beberapa bidang mata pelajaran yang sesuai.

2. Pembelajaran terpadu didasarkan pada pendekatan inquiry yang bertujuan untuk meningkatkan keaktifan peserta didik.

3. Pembelajaran terpadu memiliki beberapa karakteristik yaitu aktif, kontekstual, otentik, holistik, keterkaitan muatan atau materi.

4. Pembelajaran terpadu dilakukan untuk menciptakan pembelajaran yang lebih bermakna bagi peserta didik serta mengembangkan berbagai keterampilan mereka (kognitif, afektif, dan psikomotor).

5. Model pembelajaran terpadu tipe webbed merupakan model pembelajaran terpadu yang menggunakan tema sebagai dasar pembelajaran.

6. Pembelajaran terpadu tipe jaring laba-laba (webbed) merupakan representai dari pendekatan tematik untuk memadukan materi pelajaran yang berasal dari multi disiplin ilmu atau berbagai mata pelajaran yang diikat oleh satu tema.

7. Adapun langkah-langkah dalam merancang pembelajaran terpadu tipe webbed yaitu memetakan Kompetensi Dasar, menentukan tema berdasarkan Kompetensi Dasar yang telah dipetakan, menjabarkan kompetensi dasar ke dalam indikator sesuai dengan tema, mengembangkan Silabus Pembelajaran, menyusun Rencana Pelaksanaan Pembelajaran.

8. Salah satu kelebihan pendekatan terpadu tipe webbed yaitu dapat memberikan gambaran yang jelas dan payung motivasi bagi siswa, artinya pendekatan tematik dapat memudahkan bagi peserta didik untuk melihat bagaimana perbedaan aktivitas dan ide-ide yang berkaitan dalam pembelajaran.

9. Sedangkan kekurangan pendekatan terpadu tipe webbed diantaranya yaitu kurang efektif dalam penggunaan waktu serta lebih terpusat pada kegiatan pembelajaran dibandingkn dengan pengembangan konsep karena konten yang termuat dalam tema biasanya bersifat dangkal.

\section{B. Saran}

Adapun saran yang dapat diberikan sebagai berikut:

1. Pemerintah: sebagai pihak yang bertanggung jawab dalam penyusunan dan pengembangan kurikulum, dapat menggunakan pendekatan terpadu tipe webbed sebagai salah satu landasannya karena susuai dengan karakteristik materi pelajaran di tingkat dasar.

2. Guru: melalui pendekatan terpadu tipe webbed diharapkan dapat menciptakan kegiatan pembelajaran yang lebih menarik bagi siswa sehingga dapat meningkatkan motivasi serta dapat mengembangkan berbagai potensi dan keterampilan siswa.

Pembelajaran Terpadu.........................................................................Syafrilianto 


\section{DAFTAR PUSTAKA}

Depdikbud, Model-Model Pembelajaran Dirjen Pendidikan Dasar dan Menengah Departemen Pendidikan Nasional. Jakarta: Depdikbud, 2002.

Fogarty, R, The Mindful School: How to Integrate The Curricula. Illinois: IRI/ Skylight Publishing, Inc, 1991.

Muhajir dan Khatimah,YR, Buku Pedoman Pengembangan dan Implementasi Kurikulum 2013. Jakarta: Kemendikbud, 2013.

Rizka, P, Pembelajaran Terpadu Model Webbed, 2013 [Online]. Tersedia: http://rizkapratiwijaya.blogspot.com/2013/04/pembelajaran-terpadu-modelwebbed.html[ 8 September 2014].

Trianto, Model Pembelajaran Terpadu. Jakarta: Bumi Aksara, 2014. 